\title{
Reálopciók az üzleti inkubációs folyamatban
}

\author{
Posza Alexandra \\ Pécsi Tudományegyetem
}

\begin{abstract}
A TANULMÁNY CÉLJA
A reálopció elmélet vizsgálatára az elmúlt több mint negyven évben több iparág és kutatási terület esetében tettek kísérletet, azonban vannak olyanok, amelyek kevesebb figyelmet kaptak. Egy lehetséges, még kiaknázatlan területe a reálopció alkalmazásának az üzleti inkubáció folyamata, amely az újonnan induló vállalkozások sikerének kulcsát jelentheti. A tanulmány fókuszában az üzleti inkubációs folyamat, valamint a reálopció elmélet áll, és célja bemutatni az üzleti inkubációs folyamat lépéseit, döntési fázisait mind az üzleti inkubátor, mind pedig a résztvevők szempontjából, emellett egy olyan keretrendszert kialakítani, amely biztosítja az inkubátorok hatékony müködését reálopciók azonosítása és menedzselése segítségével.
\end{abstract}

\section{ALKALMAZOTT MÓDSZERTAN}

A bizonytalanság, valamint a menedzseri rugalmasság feltárása és modellbe ágyazása révén a reálopció elmélet alkalmazásával vizsgálom az üzleti inkubációs folyamatban rejlő opciós lehetőségeket. A kvalitatív elemzés során azonosítom az üzleti inkubációs folyamatban rejlö halasztási, elvetési, szakaszos, növekedési, méretváltoztatásra irányuló reálopciókat, és meghatározom ezek alkalmazásának előnyeit pozitív jellemzőik hangsúlyozása mellett.

\section{LEGFONTOSABB EREDMÉNYEK}

Bár számos szakirodalmi forrás az inkubációs folyamat modelleket „fekete doboz” szemléletben kezeli, belátható, hogy a modell folyamat- és struktúraorientált természetének figyelembevétele egyaránt lehetővé teszi annak mélyreható vizsgálatát, és következtetéseket enged levonni az inkubációs folyamatban rejlő potenciálról. A folyamatban időzítési, szakaszos, elvetési, valamint növekedési reálopciók is azonosíthatók, amelyek lehívása vagy elvetése révén biztosítják a vállalati értékteremtés megvalósulását.

\section{GYAKORLATI JAVASLATOK}

A reálopciók menedzselése révén az üzleti inkubátoroknak müködési hatékonyságuk növelésére, valamint vállalati értékteremtésre nyílik lehetőségük. A tanulmány, illetve a későbbi kutatások gyakorlati szakemberek számára biztosítanak újfajta megközelítést, a reálopciós logika beépítésének, valamint a reálopciós értékelés alkalmazásának lehetőségét.

Kulcsszavak: üzleti inkubációs folyamat, reálopció elmélet, bizonytalanság, rugalmasság

DOI: https://doi.org/10.15170/MM.2019.53.04.04 


\section{BEVEZETÉS}

Az üzleti inkubátorok segíthetnek csökkenteni a sikertelen vállalkozások számát és növelni a túlélési arányokat (Moreira \& Carvalho 2012, Ayatse et al. 2017). Az üzleti inkubátorok üzleti tanácsadást, fizikai infrastruktúrát biztosítanak a vállalkozások számára, valamint inkubációs programok keretében lehetőséget teremtenek az inkubációs folyamat szakmai támogatására. A lehetséges résztvevők kiválasztásával indul az üzleti inkubáció folyamata, mely már önmagában kockázatot rejt, az inkubátorba bevont vállalkozások biztos sikere is megkérdőjelezhetö, azonban a bizonytalanság értékteremtô szerepének, valamint a menedzseri flexibilitás szem elött tartása mellett lehetőség nyílik a folyamat elömozdítására. A szakirodalomban számos példát láthatunk az üzleti inkubációs folyamat elemzésére, különböző aspektusból történő vizsgálatára, azonban kevés olyan esettel találkozunk, amely a reálopció elmélet szempontjából vizsgálja az üzleti inkubáció folyamatát. A reálopciós megközelítés értékes hozzájárulást adhat az üzleti inkubációs folyamat megértéséhez a bizonytalanság, valamint a rugalmasság szem előtt tartása mellett. Tanulmányomban az üzleti inkubációs folyamatban rejlö reálopciók feltárására, azonosítására törekszem azon kutatási kérdések mentén, hogy az üzlet inkubációs folyamatban mely típusú reálopciók azonosíthatók, és az egyes reálopciók miként járulnak hozzá az inkubátorok értékteremtő képességéhez. Elsőként az üzleti inkubációs folyamatot, illetve az azt leíró modelleket mutatom be, majd a reálopció elméletet ismertetem különös tekintettel az egyes reálopció típusokra. Ezt követően egy saját koncepcionális üzleti inkubációs modell segítségével ismertetem az egyes fázisokban rejlő reálopciókat és azok üzleti inkubátorra gyakorolt hatását vizsgálom.

\section{AZ ÜZLETI INKUBÁTOR}

Az üzleti inkubátorok többségét egyrészt a gazdasági fejlődés, egy adott régió gazdasági helyzete (Mian 1997) az innováció, a munkahelyteremtés (Carree \& Thurik 2010) eszközének tekintik, másrészt egy olyan szervezetnek, amely új, gyors növekedésủ vállalatok inkubálását szolgálja (Hackett \& Dilts 2004a).

Az üzleti inkubáció szakirodalmának egyik része az üzleti inkubátorok elméletével, modelljeivel foglalkozik, valamint az üzleti inkubátorok alapításának célját és menedzselését vizsgálja (Grimaldi \& Grandi 2005, Aernoudt 2004), míg a másik része az inkubátorok értékelésére fókuszál, beleértve azokat a tényezőket, amelyek a sikeres inkubátor jellemzőiként írhatók le (Mian 1996, Colombo \& Delmastro 2002, Aerts et al. 2007, McAdam \& McAdam 2008).

Az üzleti inkubáció definiálására számos szerző, eltérő aspektusból tett kísérletet és egy fejlődési ívet is tulajdonítanak neki (Lalkaka 2006). Al-Mubaraki és Busler (2013) gazdasági és társadalmi programként írja le, amely intenzív támogatást nyújt a start-up vállalatok számára, ily módon felkészíti őket vállalkozásindításra, valamint fejlesztéseik és sikerük akcelerálására. Ayatse et al. (2017) emellett egyedülálló intézményi megállapodásként tekint rá, amely egy közösségen belül elsősorban a vállalkozói kultúra fejlesztésére irányul.

Sok esetben találkozunk start-up sikertörténetekkel, azonban a legtöbb induló vállalkozás nem tudja kihasználni maximálisan a benne rejlő potenciált, mivel többek közt az alapítók gyakran nem rendelkeznek vezetői képességekkel vagy az innovációjukat életképessé tevő erőforrásokkal (Bøllingtoft \& Ulhøi 2005). Ezt a rést töltötték ki az üzleti inkubátorok azzal, hogy biztosították a támogató környezetet az újonnan alakuló vállalkozások számára. Az üzleti inkubátor felelőssége, hogy olyan együttmüködést alakítson ki, amely támogatja az inkubáltakat az információk elérésében, valamint ezáltal tanulási folyamat révén hozzájárul a kompetenciáik fejlődéséhez. Az inkubátorok második generációja kiegészítő szolgáltatásaik révén új inkubációs modellt alakított ki, amelynek célja a nagy növekedési potenciállal rendelkező üzleti ötletek sikeres vállalkozássá alakítása, valamint túlélőképességének kibontakoztatása (Bergek \& Norrman 2008). Az üzleti inkubátorok az innováció és a vállalkozások támogatásának egyik legfontosabb pillérévé váltak (Gerlach \& Brem 2015).

\section{Az üzleti inkubációs folyamat és modelljei}

Az üzleti inkubációs folyamat a jelentkezők kiválasztásával indul, majd ellenőrzik és erőforrásokkal támogatják öket, amíg végig mennek a különböző fejlesztési fázisokon (Moreira \& Carvalho 2012, Ayatse et al. 2017). Aernoudt (2004) szerint az üzleti inkubáció fö célja sikeres vállalatok létrehozása, amelyek életképesen és a saját lábukon állva ésszerủ határidőn belül hagyják el az üzleti inkubátort. Az inkubátoré pedig, hogy megfogalmazza az inkubáltak által elvárt kimeneti követelményt.

$\mathrm{Az}$ üzleti inkubációs folyamat leírására a 1980-as évektől kezdődően számos modell 
született (Campbell et al. 1985, Smilor 1987, Bergek \& Norman 2008). Az első inkubációs folyamatot leíró modellt Campbell et al. (1985) alkotta meg, amelyben olyan tevékenységeket írt le, amelyek az ötletek vállalattá formálását támogatják. Ide sorolandó az igényfelmérés, a vállalatot támogató tevékenységek kiválasztása és az ellenőrzés, a finanszírozás biztosítása, valamint a hozzáférés az inkubátor hálózatához. Smilor (1987) kiterjesztette a Campbell modellt, amelyre már a rendszerszemlélet jellemző, és ahol az inkubációs folyamat új vállalat léetrehozását, a struktúrát és a hitelességet, valamint a kulcserőforrásokat biztosítja az inkubáltak számára. Hackett és Dilts (2004b) szintén Campbell et al. (1985) modelljét fejlesztette tovább holisztikus inkubációs modelljében. Megközelítésük szintén az eredményekre fókuszál, vagyis az úgynevezett „feketedoboz” szemléletet alkalmazza.
A „feketedoboz” azokat a jellemzőket tárja fel, amelyek a külső megfigyelők által láthatók, azonban figyelmen kívül hagyja a belső részleteket. Hackett \& Dilts (2004b) a reálopciókat hívta segítségül az inkubációs folyamat elemzéséhez.

$\mathrm{Az}$ üzleti inkubációs folyamat három nagyobb szakaszra bontható (1. ábra). Az üzleti inkubációt megelőző fázis, a pre-inkubáció fázisa Fogarassy (2016) szerint a tanulás és fejlesztés szakaszát jelenti a projektek számára, ahol támogatást kaphatnak saját üzleti ötletük fejlesztéséhez. A pre-inkubáció programok keretében azon projekteket támogatják üzleti pozíciójuk erősítésében, amelyek nem állnak készen még az inkubációs programra. A pre-inkubációs fázis végén a projektnek lehetősége van formálisan, vagy ötlet- vagy üzletiterv-versenyek révén bekerülni az üzleti inkubátorokba.

\section{1. ábra: Az üzleti inkubáció folyamat modellje}

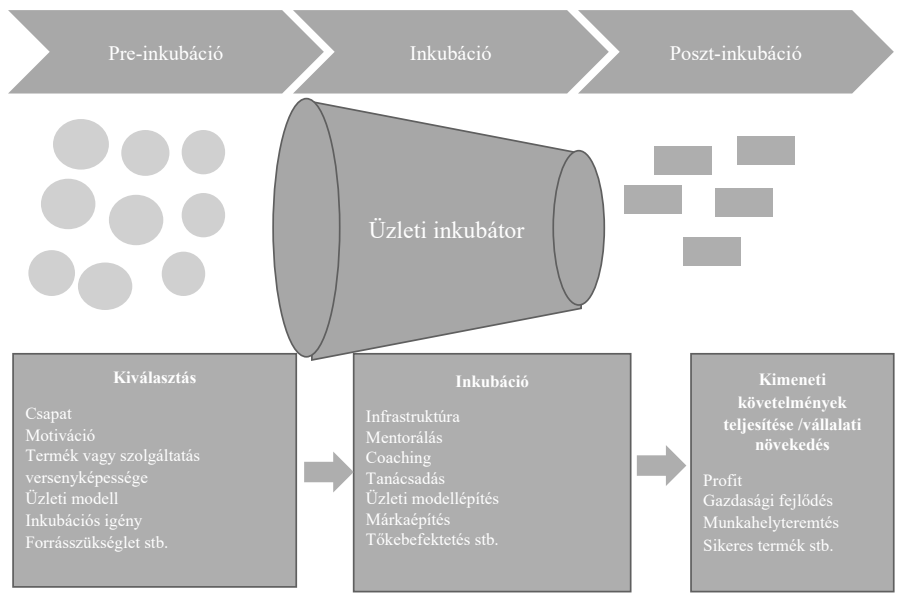

Forrás: saját szerkesztés

A pre-inkubációs programok szürőként is szolgálnak az inkubátorok kiválasztási folyamata során, segítik abban a vállalkozókat, hogy csökkentsék a kockázatot, valamint hogy információval alátámasztott, megfelelő döntést hozzanak az új vállalkozás indításakor, és megelőzzék a későbbi esetleges sikertelenséget (CIE 2014). A projektek kiválasztást, szürését az inkubátorok különböző, általuk meghatározott értékelési szempontok mentén végzik. Colombo és Delmastro (2002) rámutatott arra, hogy az üzleti inkubátorok kiválasztási folyamata befolyásolja a jelentkezők minőségét. A sikeres kiválasztást követően az újonnan belépö projektek úgynevezett inkubációs tervet készítenek, amely meghatározza a célokat, mérföldköveket, a testre szabott szolgáltatásokat és ütemezést, a pénzügyi tervet, valamint a tökebefektetés feltételeit.

Az üzleti inkubációs szakasz végén az adott inkubátor kimeneti követelményeinek megfelelően értékelik a projektek elért eredményeit, az adott ötlet piacra bocsátásának sikerességét. Egyes szakirodalmi források szerint a posztinkubációs szakasz 
vizsgálati tényezői, kimeneti követelményei közé tartoznak többek közt a jövedelmezőség; a gazdasági fejlődés, hozzájárulás a régió fejlődéséhez; a munkahelyteremtés; a sikeres termékek; a látható, életképes vállalkozás; az iparági versenyképesség; a globális hálózatok, valamint a termék/folyamat fejlesztés (Stephens \& Onofrei 2012). Fontos kiemelni tehát, hogy mint az 1 . ábrán is látható, a poszt-inkubációs fázis nem az üzleti inkubáció egyik lépése, hanem az inkubátor egy olyan szolgáltatását is jelentheti, amelyben monitoringot, a tömegtermelés hozzáférhetőségét, a menedzseri kapacitásbővítést, valamint a hálózat fejlesztés lehetöségét biztosítja (Kusuma et al. 2015).

Az üzleti inkubációs folyamatmodellek segítik a folyamat megértését, átláthatóságát, valamint segítenek azonosítani azokat a tevékenységeket, amelyek mind az inkubátor, mind a projektek számára kiemelt hasznossággal bírnak. A modellek azonban nem biztosítják a döntési rugalmasság beépítését, amely az egyes kiegészítő szolgáltatások igénybevétele és azok időzítése esetében fontos. Erre kínál megoldást a reálopció elmélet.

\section{A REÁLOPCIÓ ELMÉLET}

A reálopciók definiálásakor egyrészt annak a tisztázása fontos, hogy mit értünk benne „opció”, másrészt, tartalmát tekintve mit értünk „,reál” alatt. Az opció ebben a kontextusban többet jelent egyszerú alternatívánál vagy lehetőségnél. A reálopció egy jog, de nem kötelezettség, amely elöre meghatározott áron, egy elöre meghatározott időpontban egy intézkedés végrehajtását jelenti (Copeland \& Antikarov 2001). A reálopció kifejezést Myers (1977) használta először, reálopciónak nevezte azokat a lehetőségeket, amelyek a reáleszközök megszerzését teszik lehetővé kedvező feltételek mellett. Kogut és Kulatilaka $(2001,3)$ szerint ,a reálopció fizikai eszközökbe, humán erőforrásokba és szervezeti képességekbe történő beruházás, amely reagálási lehetőséget teremt a jövőbeni lehetséges eseményekre." E fogalom meghatározásban a szerzők a reálopciók értékteremtő-képességét hangsúlyozzák a beruházási lehetőségek mellett. Ez egyben azt is sugallja, hogy az egyes reálopciók vállalat specifikusak, mivel a humán-erőforrás, valamint az egyes szervezetekben rejlő képességek egyaránt a vállalat egyediségét helyezik előtérbe. Csapi és Ratting (2013) szerint a reálopció-elmélet központi premisszája szerint a menedzseri döntések fókuszában a flexibilitást növelö, a bizonytalanságot csökkentö opciók létrehozatala, majd ezek lehívása (érvényesítése), vagy le nem hívása (nem érvényesítése) áll.
A reálopció elmélet tehát a bizonytalanság kezelésével foglalkozik a mai gazdasági környezet és a gyorsan változó üzleti környezet kihívásain keresztül (Dixit \& Pindyck 1994). A reálopciós világban a bizonytalanságnak értéke van a vezetői képességek miatt, amely biztosítja számukra a bizonytalan projektek menedzselését (Boyer et al. 2003). Számos stratégiai beruházás hoz létre olyan újabb, végrehajtható lehetőségeket, amelyeket egy cash flow sorozat és egy opciós halmaz együtteseként lehet szemlélni (Amram \& Kulatilaka 1999). A reálopciók tárgyalásakor annak felismeréséből kell kiindulni, hogy a jövőbeni beruházási döntést aszimmetria jellemzi, mivel az csak akkor történik meg, ha az kedvező a döntéshozó számára.

A reálopciók specifikusan biztosítják a vállalatoknak a beruházási elköteleződés késleltetését, szakaszolását, vagy a jövőbeni döntések megváltoztatását, amikor a piaci feltételek megváltoznak. Képessé teszik a vállalatot a veszteségek korlátozására és előnyöket keresnek a bizonytalanságból kialakuló kedvező fejlemények esetén (Bowman \& Hurry 1993, McGrath 1997, Trigeorgis 1996). Ez a rugalmasság jelenti a reálopciós megközelítés legfőbb előnyét a hagyományos diszkontált cash-flow eljárással szemben, amely az értékmeghatározás folyamatát csak determinisztikus módon tudja kezelni (Takács 2014).

A reálopció elmélet a menedzsment és a döntéshozatal számos különböző területére átszivárgott, a hangsúly pedig áthelyeződött a tiszta értékelési eljárásról a döntéshozatalra és az optimalizálásra. A reálopciós megközelítés alkalmazásának célja a vállalati döntéshozatalban az értékteremtés a vállalati potenciál teljes értékének megragadás révén (Boyer et al. 2003). A reálopciós döntéshozatalt Triantis \& Borison (2001) szerint három szinten lehet értelmezni, így reálopciós gondolkodásként, elemző eszköztárként, valamint szervezeti folyamatként egyaránt megjelenik. Mint gondolkodásmód, elsősorban kvalitatív értékelést tesz lehetővé, majd elemző eszköztárként kvantitatív elemzést biztosít opcióárazási modellek segítségével. Jelen tanulmányban gondolkodásmódként, vagyis kvalitatív elemzési módszertanként tekintek rá.

A reálopciós megközelítésben tárgyalt beruházások összefüggésben vannak a szekvenciális beruházási döntésekkel (Dixit \& Pindyck 1994). A szakirodalomban számos szektort és területet láthatunk, ahol alkalmazzák a reálopció elméletet, így a természeti erőforrások, a kutatás és fejlesztés, valamint az információs technológia esetében. Ezzel szemben kevés olyan esetet láthatunk, ahol az üzleti inkubációs folyamat, valamint a start-up vállalatok kerülnének a reálopciós elemzés közép- 
pontjába, pedig a fent említettek miatt jelentős bizonytalanság övezi őket.

A reálopciók vállalati portfóliójának menedzselése azonosítható a stratégiai gondolkodással (Kester 1982). Pritsch (2000) egy fázismodell keretében mutatta be a reálopció menedzselésének lépéseit, amely a reálopciók azonosításával, értékelésével, valamint azok menedzselésével foglalkozik az értékmozgatók azonosításán, rendszerbe sorolásán keresztül. Az értékteremtés maximalizálásához ki kell választani a megfelelő lépéseket, eljárásokat, amelyek a vállalat müködésének és intézkedésének leginkább megfeleltethetők. A reálopciók lehívási időpontjának meghatározása a folyamat utolsó lépése, az értékteremtés figyelembevétele mellett (Hungenberg, 2001). Csapi (2018) szerint a stratégiai reálopció-menedzsment négy lépésből álló folyamatként írható le, melyet az 1. táblázat szemléltet.

\section{1. táblázat: A stratégiai reálopció-menedzsment folyamatábrája}

\begin{tabular}{|c|c|c|c|}
\hline $\begin{array}{l}\text { 1. lépés } \\
\text { Reálopciók azonosítása }\end{array}$ & $\begin{array}{c}\text { 2. lépés } \\
\text { Reálopciók értékelése }\end{array}$ & $\begin{array}{c}\text { 3. lépés } \\
\text { Reálopciók hatékony } \\
\text { menedzselése }\end{array}$ & $\begin{array}{l}\text { 4. lépés } \\
\text { Lehívás }\end{array}$ \\
\hline $\begin{array}{l}\text { STRATÉGIAI } \\
\text { ELEMZÉS }\end{array}$ & $\begin{array}{c}\text { STRATÉGIAFORMÁLÁS } \\
\text { ÉS KIVÁLASZTÁS }\end{array}$ & $\begin{array}{c}\text { STRATÉGIA } \\
\text { ALKALMAZÁS }\end{array}$ & $\begin{array}{l}\text { STRATÉGIAI } \\
\text { DÖNTÉS }\end{array}$ \\
\hline Árnyékopciók azonosítása & $\begin{array}{c}\text { Az értékelés paramétereinek } \\
\text { meghatározása }\end{array}$ & $\begin{array}{l}\text { Reálopciók közötti } \\
\text { kölcsönhatások }\end{array}$ & $\begin{array}{c}\text { Piacra lépés, piac } \\
\text { elhagyás }\end{array}$ \\
\hline $\begin{array}{l}\text { Alap, önálló reálopciók } \\
\text { azonosítása }\end{array}$ & $\begin{array}{l}\text { Értékelési modellek } \\
\text { kiválasztása }\end{array}$ & & Szakaszolás \\
\hline $\begin{array}{c}\text { Összetett reálopciók } \\
\text { azonosítása }\end{array}$ & Értékelés & & $\begin{array}{l}\text { Termelés változ- } \\
\text { tatása, beszállítók } \\
\text { változtatása }\end{array}$ \\
\hline Reálopciók priorizálása & & & Időzítés stb. \\
\hline $\begin{array}{c}\text { EGYÉNI } \\
\text { KOMPETENCIÁK }\end{array}$ & & $\begin{array}{c}\text { SZERVEZETI, } \\
\text { VISELKEDÉSI } \\
\text { KARAKTERISZTI- } \\
\text { KÁK }\end{array}$ & INTUÍCIÓK \\
\hline
\end{tabular}

Forrás: Csapi 2018, 36.

E keretrendszer mentén lehetőség nyílik a reálopciók típusainak, értékmozgatóinak, értékelési eljárásainak, valamint a reálopciók stratégiai folyamatban, döntéshozatalban betöltött szerepének elemzésére. E folyamatból a későbbi elemzés szem előtt tartása mellett a reálopció típusokat emelem ki, majd az inkubációs folyamat kvalitatív elemzése során vizsgálom a kapcsolódási pontokat.

\section{A reálopciók típusai}

A szakirodalomban az elmúlt évtizedekben számos reálopció-tipológia született, melyek közül Trigeorgis (1996) csoportosítását emelném ki, mint több későbbi kategorizálás alapját, aki megkülönböztetett halasztási, elvetési, méretváltoztatásra irányuló (bővítési vagy szükítési), szakaszos, növekedési, leállítási/újraindítási opciókat és összetett reálopciókat.
A halasztási opció értéke abból származik, hogy biztosítja a vállalat számára a beruházási döntés időbeli eltolásának lehetőségét annak érdekében, hogy újabb információhoz jusson, amely orvosolhatja vagy csökkentheti a fennálló bizonytalanságot. Az elvetési reálopció a projekt egészének vagy egy bizonyos részének feladása, a beruházás végleges felszámolása, ha a piaci helyzet kedvezőtlenebbre fordul. A méretváltoztatásra irányuló opciók két opciót foglalnak magukban, így a bővítési és a szükítési opciókat, amelyek a piaci feltételek tartós és jelentős javulása vagy romlása esetén alkalmazhatók. A bővítési opció jelentheti a projekt kapacitásának bővítését vagy kulcskompetenciák kiterjesztését új termékekre, szolgáltatásokra, elosztási csatornákra. A szükítési opció esetében a rugalmasság abban rejlik, hogy csökkenthető a kapacitás kedvezőtlen piaci körülmények esetében, vagy szükíthető azok fókusza. A szakaszos opció esetében a 
beruházások, illetve az azokkal kapcsolatos döntéshozatal szakaszokban történik, amely csökkentheti a felsőági potenciál meglétét, azonban védelmet nyújt az alsóági kockázatokkal szemben. A projektek egyes szakaszai értékelésre kerülnek, és a vállalat vezetése ezt követően dönthet a projekt folytatásáról vagy elvetéséről. A növekedési opció lehetővé teszi a korai fázisú beruházások nyitva tartását a jövőbeli növekedési lehetőségekre. A növekedési opció hasonló a bővítési opcióhoz, azonban a kettő közötti különbség a vállalati stratégián belül elfoglalt helyében rejlik. A növekedési opciók projekten átívelő rugalmasságot biztosítanak, míg a bővítési és a szakaszos opciók projekten belüli opcióként jelennek meg. A növekedési opciók minden iparágban megtalálhatók, általánosságban az infrastruktúra alapú, magas megtérüléssel bíró projektek esetén jellemzők (Scialdone 2007). A leállitási és újrainditási opciók biztosítási típusú reálopciónak tekinthetők, amelyek révén kedvezőtlen piaci feltételek esetén a vállalatvezetés dönthet a termelés leállításáról, azonban nem zárja ki az esetleges újraindítás lehetöségét (Csapi 2018). Az összetett reálopciók pedig az elöbbiekben bemutatott reálopciókat és azok kombinációját rejtik magukban. Ezek az opciók egymástól függetlenek, de szoros kapcsolatban is lehetnek egymással. Ebben az esetben az opciós érték az alapeszköz értékébe szintén beágyazódik (Takács 2008, 2015).

\section{A REÁLOPCIÓ-ELMÉLET ALKALMAZÁSI LEHETŐSÉGE AZ ÜZLETI INKUBÁCIÓS FOLYAMATBAN}

Mint már korábban említettem, a reálopciók azonosítása és elemzése kevés esetben kap helyet a szakirodalomban, ezért kutatási rést rejt magában. Az inkubátorok tevékenysége a dinamikus piaci környezetben müködő vállalatok beruházási projektjeinek megvalósításához hasonlítható. A vállalatok is rendelkeznek egy projektportfólióval, amelynek beruházásait magas fokú bizonytalanság övezi, amely a vállalati életciklus első szakaszában a legjelentősebb, ugyanakkor lehetőség nyílik az értékteremtésre a vállalat számára (Kuratko \& LaFollette 1987) a reálopció, mint gondolkodásmód alkalmazása esetén. Hackett \& Dilts (2004b) szerint az inkubátor teljesítménye az inkubátor opcióalkotási képességén múlik, és a kiválasztási teljesítmény az inkubátor kapacitását jelenti.
Dimpfel et al. (2002) szerint a reálopciók alkalmazására rugalmasság, bizonytalanság, valamint irreverzibilitás mellett van lehetőség, így elsőként e feltételek fennállásának feltérképezése ajánlott. Az inkubátorok müködése megfeleltethető a reálopció elmélet metodológiájának a magas bizonytalanságból fakadóan, hiszen a nagy növekedési potenciállal rendelkező vállalatok kiválasztása már önmagában egy bizonytalan folyamat (Dee 2011), és kellő menedzseri rugalmasságot igényel. A reálopciók azonosítása, alkalmazása az inkubátorok számára is nagy potenciállal bírhat.

Az inkubációs folyamat reálopciós szemlélete az inkubátort úgy határozza meg, mint egy olyan vállalkozást, amely az inkubátorba való belépéshez reálopciókat hoz létre új, fiatal vállalkozások szisztematikus kiválasztásán keresztül, majd lehívja ezeket a reálopciókat az inkubáltak ellenőrzése és mentorálása révén a különböző fejlődési szakaszokban, miközben erőforrásokat biztosít számukra. Minden egyes döntési csomópont az inkubációs folyamatban módosítja az inkubáltak túlélésének valószínüségét annak függvényében, hogy az opciót miképp hívták le (Hackett 2004). Az inkubációs folyamat ilyen irányú szemlélete a szekvenciális folyamatokat idézi, amely a gyógyszeripari beruházásokban, valamint kockázati tőke befektetésekben gyakori. Az inkubációs folyamaton belül is fázisokat kell meghatározni az egyes döntési csomópontok meghatározása érdekében.

Az első és a második fejezetben leírtak alapján készítettem egy, az üzleti inkubációs folyamatot bemutató, szekvenciális folyamatot leíró ábrát (2. ábra), melynek az első döntési csomópontja a potenciális inkubáltak közötti választásnál alakul ki. Egy reálopció keletkezik arra nézve, hogy bevonja az inkubációs folyamatba az adott projektet vagy sem. A döntésben az inkubátort a korábban meghatározott változók, értékelési szempontok segítik, amelyek segítségével vizsgálható a projekt érettsége. Az inkubátor élhet egy időzitési (halasztási) reálopcióval is, amely a projekt további fejlesztését foglalja magában az üzleti inkubációt megelőző pre-inkubáció keretében. 


\section{2. ábra: Reálopciók az inkubációs folyamatban}

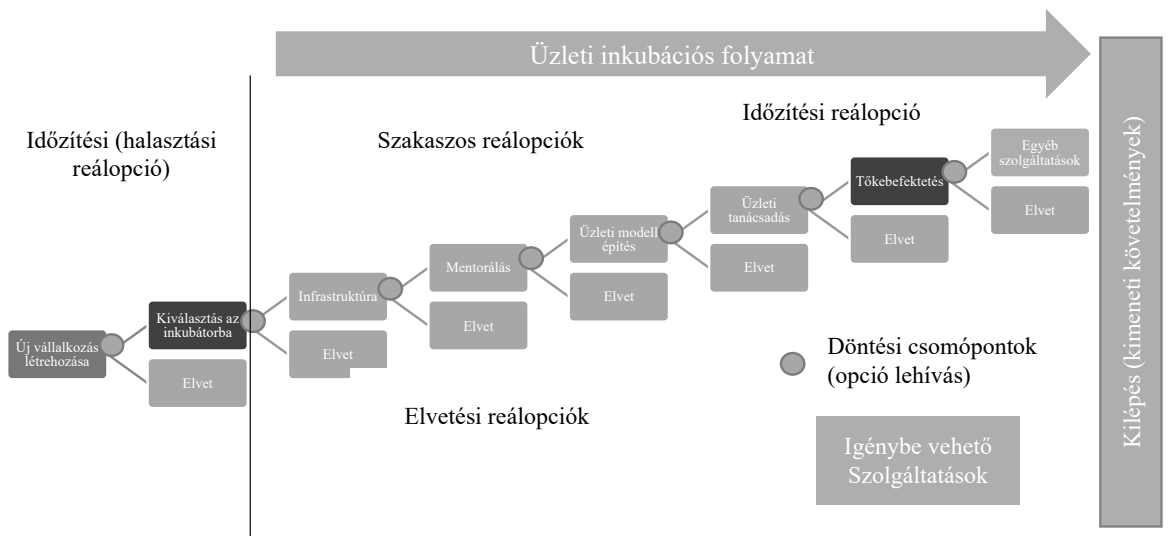

Forrás: saját szerkesztés

Miután bekerült a vállalat az üzleti inkubációs folyamatba, újabb fázisokon halad át az ötlet vagy a vállalkozás. Az egyes döntési csomópontok egyegy, korábban bemutatott kiegészítő szolgáltatást foglalnak magukba, amelyen újabb szolgáltatás igénybevételét vagy elvetését biztosítják ( $s z a$ kaszos reálopció). Jelen szemlélet esetében az inkubált döntése, hogy él-e az opciós jogával, és az adott szolgáltatás igénybevétele mellett dönt. Az inkubátor számára adott a lehetőség, hogy biztosítsa az adott projekt számára a szolgáltatást, vagy sem, valamint a projekt folytatás, vagy elvetése mellett dönthet (elvetési reálopció). A projekt inkubációs folyamaton való haladása mentén lehetségessé válik karakterisztikáinak megfelelően annak bővítése vagy szükítése (bővitési/szükitési reálopció).

A projekt inkubációs programba való bekerülése mellett fontos mérföldkő a tőkebefektetés megszerzése, amely az inkubátor által meghatározott kritériumok teljesítése esetén lehetséges. Ennek megvalósításához a projektnek az ehhez tartozó feltételeket teljesítenie kell (szakaszos reálopció), majd ezt követően nyílik lehetősége a tőkebefektetés megszerzésére, melynek időzítése kiemelt fontosságú (időzítési reálopció).

Az egyes döntési pontoknak összefüggésben kell lennie a kimeneti követelményekkel, így az utolsó döntési fázis a vállalkozás piacra bocsátása vagy elutasítása. Majd a poszt-inkubációs fázisban a projekt utánkövetésére, illetve a projekt további növekedésére van lehetőség (növekedési reálopció).
A szekvenciális üzleti inkubációs folyamatban rejlő reálopciók menedzselése az inkubátor számára számos lehetőséget tartogat, melynek első lépése, mint az 1. táblázatban is látható, a folyamatmodellben bemutatott (árnyék) reálopciók azonosítása, amely akár újabb reálopciók generálását is lehetővé teszi. Itt az egyéni kompetenciáknak nagy szerep jut. Ezt követi a reálopciók értékelése, amely a megfelelő értékelési modellek kiválasztásra révén biztosít lehetőséget az értékteremtés mértékének meghatározására, valamint a projektek értékelésére. Harmadik lépése a reálopció menedzselési folyamatnak a reálopciók közti kölcsönhatások elemzése a szervezeti karakterisztikák figyelembevétele mellett, majd ezt követi az utolsó lépés, vagyis a stratégiai döntéshozatal, az egyes projekthez köthető szakaszok (kiegészítő szolgáltatások) meghatározása és időzítése, esetleges változtatások alkalmazása, valamint az inkubációs utolsó fázisának tekinthető piacra vitele vagy elvetése.

\section{ÖSSZEGZÉS}

Az üzleti inkubátorok egyre inkább növekvő szerepével találkozhatunk annak köszönhetően, hogy nagy növekedési potenciált és a siker lehetőségét biztosítják a start-up vállalkozások számára. A reálopció elmélet megragadja a start-up vállalkozások lényegi tulajdonságait, valamint számos jövőbeli kutatási lehetőséget tartogat. Tanulmányomban az üzleti inkubációs folyamat egyes fázisaiban, döntési csomópontjaiban rejlö reálopciók azonosítására és kvalitatív elemzését 
mutattam be. A teljes üzleti inkubációs folyamatban megtalálhatók a reálopciók, amelyek hozzájárulnak az inkubátor értékteremtő képességének növeléséhez, valamint az inkubált projektek piacra lépésének elősegítéséhez. A reálopciók menedzselése kiemelt fontosságú, amely az üzleti inkubáció projektportfóliójának hatékony menedzselését biztosítja. A tanulmányban koncepcionális modellt alkotta az inkubátorok jellemzőinek és a reálopcióban rejlö lehetőségek összevetésével, ami végig vezet az üzleti inkubációs folyamaton. A terület számos további elemzési lehetőséget rejt magában, így a kvalitatív értékelés mellett a kvantitatív elemzés esélyét. A reálopció elmélet mint értékelési eljárás biztosítja az inkubátorba bekerült vállalkozások opciós értékelését, valamint azok értékének meghatározását a hagyományos értékelési eljárásokon túlmutatóan, mely a magas szintü bizonytalansággal övezett start-up vállalkozások esetében kiemelt jelentőségü. A kvantitatív értékelés gyakorlati példán keresztüli alkalmazhatóságát is érdemes lenne bemutatni, akár üzleti, akár egyetemi inkubátorok folyamatainak értékteremtő képességének vizsgálatán keresztül.

\section{HIVATKOZÁSOK}

Aernoudt, R. (2004), “Incubators: Tool for entrepreneurship?" Small Business Economics, 23 127-35 DOI: https://doi.org/10.1023/b:sbej.0000027665.54173.23

Aerts, K., Matthyssens, P., Vandenbempt, K. (2007), "Critical role and screening practices of European business incubators", Technovation, 27 254-67 DOI: https://doi.org/10.2139/ ssrn. 870244

Al-Mubaraki, H. A. and Busler, M. (2013), "Business incubation as an economic development strategy: A literature review", International Journal of Management, 30 1, 362-72

Amram, M., Kulatilaka, N. (1999), Real Options: Managing strategic investment in an uncertain world, Harvard Business School Press, Boston, MA.

Ayatse, F. A., Kwahar, N., Iyortsuun, A. S. (2017), „Business incubation process and firm performance: an empirical review", Journal of Global Entrepreneurship Research, 7 2, 1-17 DOI: https://doi.org/10.1186/s40497-016-0059-6

Bergek, A., Norrman, C. (2008), "Incubator best practice: a framework", Technovation, 28 1-2, 20-8 DOI: https://doi.org/10.1016/j.technovation.2007.07.008

Bøllingtoft, A., Ulhøi, J. P. (2005), “The networked business incubator - leveraging entrepreneurial agency?" Journal of Business Venturing, 202 , 265-90

Bowman, E. H., Hurry, D. (1993), “Strategy through the Option Lens: Are Integrated of Resource Investments and the Incremental-Choice Process", The Academy of Management Review, 18 4, 760-82 DOI: https://doi.org/10.2307/258597

Boyer, M., Christoffersen, P., Lassere, P. and Davlov, A. D. (2003), "Value Creation, Risk Management, and Real Options", Centre for Interuniversity Research and Analysis on Organisations, https://www.researchgate.net/ publication/4816345_Value_crea-tion_risk management_and_real_options (Letöltve: 2018.10.02)

Campbell, C., Kendrick, R. C., Samuelson, D. C. (1985), "Stalking the latent entrepreneur: business incubators and economic development", Economic Development Review, 3 2, 43-9

Carree, M. and Thurik, A. (2010), "The Impact of Entrepreneurship on Economic Growth", in Acs, Z., Audretsch, D. (eds.), International Handbook of Entrepreneurship Research, 2/e, London: Springer, pp. 557-94 DOI: https://doi. 
org/10.1007/0-387-24519-7_17

Cleantech Incubation Europe (CIE) (2014), Cleantech Incubation Policy and Practice, http://cleantechincubation.eu/wp-content/ uploads/2012/07/CleantechIncubati-on-Practice-and-Practice-Handbook.-June-2014.pdf (Letöltve: 2018.11.03)

Colombo, M. G., Delmastro, M. (2002), "How effective are technology incubators? Evidence from Italy", Research Policy, 31 7, 1103-22 DOI: https://doi.org/10.1016/s00487333(01)00178-0

Copeland, T. E., Antikarov, V. (2001), Real Options: A Practitioner's Guide. Texere

Csapi V. (2018), "A reálopciók első 40 éve", Vezetéstudomány, 49 9, 34-45 DOI: https://doi. org/10.14267/veztud.2018.09.03

Csapi V. - Ratting A. (2011): “A reálopciós megközelítés alkalmazása az építészetben”, Marketing \& Menedzsment, 47 Különszám,. 56-68

Dee, N. J., Livesey, F., Gill, D., Minshall, T. (2011), Incubation for Growth: A Review of the Impact of Business Incubation on New Ventures with High Growth Potential, NESTA, London, available at: www.nesta.org.uk/library/documents/ Incubationfor-Growthv11.pdf

Dimpfel, M., Habann, F. and Algesheimer, R. (2002), "Real Options Theory, Flexibility and the Media Industry", The International Journal on Media Management, 4 4, 261-72 DOI: https://doi.org/10.1080/14241270209390007

Dixit, A., Pindyck, R. (1994), Investment under Uncertainty, Princeton, NJ: Princeton University Press

Fogarassy Cs. (2016), A tiszta fejlesztések inkubációjának legjobb gyakorlata inkubátor szervezetek számára, L'Harmattan Kiadó: Budapest

Gerlach, S., Brem, A. (2015), ,What determines a successful business incubator? Introduction to an incubator guide", International Journal of Entrepreneurial Venturing, 7 3, 286-307 DOI: https://doi.org/10.1504/ijev.2015.071486

Grimaldi, R., Grandi, A. (2005), "Business incubators and new venture creation: an assessment of incubating models", Technovation, 252 , 111-21 DOI: https://doi.org/10.1016/s01664972(03)00076-2

Hackett, S. M. (2004), "Real Options and the Option to Incubate: an Exploratory Study of the Process of Business Incubation". Dissertation executive summary. Letöltve: http://ssrn.com/ abstract=1260438 DOI: https://doi.org/10.2139/ ssrn. 1260438

Hackett, S. M. and Dilts, D. M. (2004a), “A real option-driven theory of business incubation", Journal of Technology Transfer, 29 41-54 DOI: https://doi.org/10.1023/b:jott.0000011180.19370.36

Hackett, S. M. and Dilts, D. M. (2004b), “A Systematic Review of Business Incubation Research", Journal of Technology Transfer, 29 1, 55-82 DOI: https://doi.org/10.1023/b:jott.0000011181.11952.0f

Hungenberg, H. (2001), Strategisches Management in Unternehmen: Ziele - Prozesse - Verfahren. Wiesbaden: Springer. DOI: https://doi. org/10.1007/978-3-322-94533-4

Kester, W. (1984), "Today's Options for Tomorrow's Growth", Harvard Business Review, 62 2, 153-60

Kogut, B. and Kulatilaka, N. (2001), "Capabilities As Real Options", Organization Science, 12 6, 744-58 DOI: https://doi.org/10.1287/ orsc.12.6.744.10082

Kuratko, D. F., and LaFollette, W. R. (1987), "Small business incubator for local economic development", Economic Development Review, 5 2, 49-55

Kusuma, C., Sutopo, W., Yuniaristanto, H. S. and Nizam, M. (2015), 'Incubation Schemme of the University Spin Off to Commercialize the Invention in Sebelas Maret University". In: Ao, S. I., Castillo, O., Douglas, C., Feng, D. D. and Lee, J. (eds.): Proceedings of the International MultiConference of Engineers and Computer Scientists 2015. Vol. 2, Hong Kong, Newswood, 841-4

Lalkaka, R. (2006), "Technology business incubators: critical determinants of success", Annals of the New York Academy of Sciences, 7 8, 270-90 DOI: https://doi.org/10.1111/j.1749-6632.1996. tb24870.x

McAdam, M. and McAdam, R. (2008), "High tech start-ups in University Science Park incubators: The relationship between the start-up's lifecycle progression and use of the incubator's resources", Technovation, 28 277-90 DOI: $\quad$ https://doi.org/10.1016/j.technovation.2007.07.012

McGrath, R. (1997): “A Real Options Logic for Initiating Technology Positioning Investments", Academy of Management Review, 22 4, 974-96 DOI: https://doi.org/10.5465/ amr.1997.9711022113

Mian, S. A. (1996), “Assessing Value-added Contributions of University Technology Business Incubators to Tenant Firms", Research Policy, 25 3, 325-35 DOI: https://doi.org/10.1016/00487333(95)00828-4 
Mian, S. A. (1997), “Assessing and Managing the University Technology Business Incubator: An Integrative Framework", Journal of Business Venturing, 12 4, 251-85 DOI: https://doi. org/10.1016/s0883-9026(96)00063-8

Moreira, A. C. and Carvalho, M. F. S. (2012), "Incubation of New Ideas: Extending Incubation Models to Less-Favored Regions" In: Burger-Helmchen, T. (2012): Entrepreneurship - creativity and innovative business models, Rijeka (Croatia): InTech. p. 190. DOI: https:// doi.org/10.5772/36705

Myers, S. C. (1977), "Determinants of Corporate Borrowing", Journal of Financial Economics, 5 2, 147-75 DOI: https://doi.org/10.1016/0304$405 \times(77) 90015-0$

Pritsch, G. (2000), Realoptionen Als Controlling-Instrument.Wiesbaden: GablerVerlag. DOI: https://doi.org/10.1007/978-3-663-08910-0

Scialdone, P. (2007), Valuing Managerial Flexibility: Challenges and Opportunities of the Real Option Appoach in Practice, Cuvillier Verlag, Göttingen

Smilor, R. W. (1987), "Commercialising Technology through New Business Incubators", Research Management, 30 5, 36-41 DOI: https://doi.org/10.1080/00345334.1987.11757 061

Stephens, S., Onofrei, G. (2012), „Measuring Business Incubation Outcomes", Entrepreneurship and Innovation, 14 4, 277-85. DOI: https:/doi. org/10.5367/ijei.2012.0094

Takács A. (2008), "Reálopciók: a jövőbeli lehetőségek értékelése", Közgazdász Fórum, 11 $12,47-55$

Takács A. (2014), "The Relationship between Appraised Company Values and Future Stock Prices in the International Banking Sector". International Research Journal of Finance and Economics, 9 118, 113-23 DOI: https://doi. org/10.7176/rjfa/10-14-09

Takács A. (2015), Vállalatértékelés magyar számviteli környezetben, második, bővített kiadás, Budapest: Perfekt

Triantis, A., Borison, A. (2001), "Real Options: State of the Practice", Journal of Applied Corporate Finance, 14 2, 8-24. DOI: https://doi. org/10.1111/j.1745-6622.2001.tb00327.x

Trigeorgis, L. (1996), Real Options: Managerial Flexibility and Strategy in Resource Allocation, Cambridge, MA: MIT Press 
Posza Alexandra tanársegéd poszaa@ktk.pte.hu

Pécsi Tudományegyetem

Közgazdaságtudományi Kar

Pénzügy és Számvitel Intézet

\section{Real options in business incubation process}

\section{THE AIMS OF THE STUDY}

Real option theory has been analyzed for more than forty years in more industries and research areas but some of these have received less attention. One potential but yet untapped area of real option theory application is the business incubation process, which can be a key success factor of start-up companies. The study focuses on the business incubation process and the real option theory and aims to present the steps of the business incubation process and the decision-making phases for both the business incubator and the participants, and to develop a framework that ensures the efficient operation of incubators.

\section{METHODOLOGY}

By exploiting and modelling uncertainty and managerial flexibility I examine the opportunities in business incubation process applying real option theory. In the course of the qualitative analysis I identify the different types of real options inherent in the business incubation process and determine the benefits of applying them as well as emphasizing their positive features.

\section{MOST IMPORTANT RESULTS}

Although many literature review sources treat incubation process models with a "black box" approach, considering the model process and its structure-oriented nature enables its in-depth analysis and conclusion about the potential in the incubation process. In the process we can also identify timing, staging, contract and growth real options and exercising or discarding these options ensures corporate value creation.

\section{RECOMMENDATIONS}

Identifying and exploiting real options gives scope for business incubators to achieve operational effectiveness and value-creation. They study and the subsequent research provide new approach to practitioners, including the real option logic and use real option valuation.

Keywords: business incubation process, real option theory, uncertainty, flexibility 